\title{
Genotype by environment interactions for body weight in Mediterranean buffaloes using reaction norm models
}

\author{
Interacción genotipo $\times$ ambiente para peso corporal de búfalos Mediterráneos utilizando modelos de \\ norma de reacción
}
Interação genótipo $\times$ ambiente para peso corporal de búfalos Mediterrâneos utilizando modelos de norma de reação

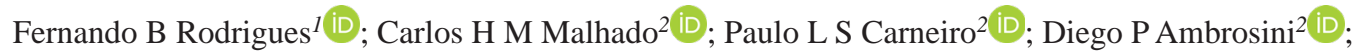
Marcos P G Rezende ${ }^{2 *}$ (D); Riccardo Bozzi ${ }^{3}$ (iD); Jiuzhou Song 4 (iD).
\end{abstract}

${ }^{1}$ Federal Institute of Northern Minas Gerais, Minas Gerais, Brazil
${ }^{2}$ State University of the Southwest of Bahia, Jequié, Bahia, Brazil
${ }^{3}$ DISPAA - University of Firenze, Firenze, Italy
${ }^{4}$ University of Maryland, College Park, Maryland, United States

To cite this article:

Rodrigues FB, Malhado CHM, Carneiro PLS, Ambrosini DP, Rezende MPG, Bozzi R, Song J. Genotype by environment interactions for body weight in Mediterranean buffaloes using reaction norm models. Rev Colomb Cienc Pecu 2021; 34(3): 166-176. DOI: https://doi.org/10.17533/udea.rccp.v34n2a05

\begin{abstract}
Background: Buffalo breeding has significantly increased in Brazil over recent years. However, few genetic evaluations have been conducted. Objective: To assess Genotype x Environment Interactions in the Mediterranean Water Buffalo in Brazil, for weight at 205 days of age, using reaction norm models via random regression. Methods: Data for buffaloes born between 1990 and 2014 were collected from five farms ascribed to the Brazilian Buffaloe Improvement Program, located in the North (1), Northeast (1), South (2) and Southeast (1) regions of Brazil. The initial database consisted of 5,280 observations at 205 days of age (W205). We assessed fit using two hierarchical reaction norm models: a two-step $\left(\mathrm{HRNM}_{2 \mathrm{~s}}\right)$ and a one-step $\left(\mathrm{HRNM}_{1 \mathrm{~s}}\right)$. Model fit was estimated using the Deviance Information Criterion, Deviance Based on Bayes Factors and Deviance based on Conditional Predictive Ordinate. The environmental descriptors were created to group individuals into common production environments based on year, season, herd and sex. Results: The best fit was obtained for the hierarchical reaction norm model with one-step $\left(\mathrm{HRNM}_{1 \mathrm{~s}}\right)$. Direct heritability estimates for this model ranged from 0.17 to 0.67 and the maternal heritability from 0.02 to 0.11 with increasing environmental gradient. Lower correlations among the sire classifications were obtained in comparison with $\mathrm{HRNM}_{1 \mathrm{~s}}$ in environments with low and high management, confirming the presence of genotype $\mathrm{x}$ environment interactions. Conclusion: We recommend a wider application of genetic evaluation in buffalo aimed at identifying optimal genotypes within specific environments.
\end{abstract}

Received: April 11, 2019; accepted: July 11, 2020

*Corresponding author. Av. José Moreira Sobrinho s/n Cep: 45206-190. Bairro Jequiezinho, Jequié/BA.

E-mail: mpgrezende@gmail.com 
Keywords: bayesian inference; breeding value; buffaloes; environment; environmental gradient; genetic evaluation; genotypes; genotype by environment interaction; hierarchical reaction; rank correlations; reaction norm models.

\section{Resumen}

Antecedentes: La cría de búfalos ha aumentado significativamente en Brasil en los últimos años. Sin embargo, se han realizado escasas evaluaciones genéticas. Objetivo: Evaluar las interacciones genotipo x ambiente en búfalos de agua Mediterráneos criados en Brasil, para peso a los 205 días de edad, utilizando modelos de reacción mediante regresión aleatoria. Métodos: Los datos de búfalos nacidos entre 1990 y 2014 se obtuvieron de cinco granjas situadas en el Norte (1), Nordeste (1), Sur (2) y del Sureste (1) de Brasil. Todas estas haciendas participan en el Programa Brasileño de Mejoramiento de Búfalos. Nuestra base de datos inicial consistió de 5.280 observaciones a los 205 días de edad (P205). Evaluamos el ajuste utilizando dos modelos de norma de reacción jerárquica: de dos pasos $\left(\mathrm{HRNM}_{2 \mathrm{~s}}\right)$ y un paso $\left(\mathrm{HRNM}_{1 \mathrm{~s}}\right)$. El ajuste del modelo se estimó usando el Criterio de información de la desviación, desviación basado en los factores de bayes y desviación basado en la ordenación predictiva condicional. Los descriptores ambientales fueron creados para agrupar individuos en ambientes de producción comunes basados en año, estación, rebaño y sexo. Resultados: El mejor ajuste se obtuvo para el modelo de norma de reacción jerárquica con un paso $\left(\mathrm{HRNM}_{1 \mathrm{~s}}\right)$. Las estimaciones de heredabilidad directa para este modelo variaron de 0,17 a 0,67 y la heredabilidad materna de 0,02 a 0,11 con gradiente ambiental creciente. Las correlaciones más bajas entre las clasificaciones de los reproductores se obtuvieron en comparación con las HRNM $\mathrm{Hs}_{1}$, en ambientes con bajo y alto manejo, confirmando la presencia de interacciones genotipo x ambiente. Conclusiones: Recomendamos la aplicación amplia de la evaluación genética en búfalos para identificar genotipos óptimos en ambientes específicos.

Palabras clave: ambiente, búfalos; correlación de clasificación; evaluación genética; genotipos; gradiente ambiental; Inferencia Bayesiana; interacción genotipo por ambiente; modelos de norma de reacción; reacción jerárquica; valor genético.

\section{Resumo}

Antecedentes: A criação de búfalos aumentou significativamente no Brasil nos últimos anos. No entanto, eles raramente foram objeto de avaliações genéticas. Objetivo: Avaliar as interações genótipo x ambiente em búfalo Mediterrâneo criados no Brasil, para peso aos 205 dias de idade, utilizando modelos de reação por meio de regressão aleatória. Métodos: Os dados para búfalos de água do Mediterrâneo nascidos entre 1990 e 2014 foram coletados de cinco fazendas localizadas nas regiões Norte (1), Nordeste (1), Sul (2) e Sudeste (1) do Brasil. Todas essas fazendas participam do Programa Brasileiro de Melhoramento dos Búfalos. Nosso banco de dados inicial consistiu de 5.280 observações aos 205 dias de idade (P205). Nós avaliamos o ajuste usando dois modelos de norma de reação hierárquica: um de dois passos $\left(\mathrm{HRNM}_{2 \mathrm{~s}}\right)$ e um passo $\left(\mathrm{HRNM}_{1 \mathrm{~s}}\right)$. O ajuste do modelo foi estimado usando o Critério de informações do desvio, desvio baseado nos fatores de bayes e desvio baseado na ordenação preditiva condicional. Os descritores ambientais foram criados para agrupar indivíduos em ambientes de produção comuns baseados em ano, estação, rebanho e sexo. Resultados: $\mathrm{O}$ melhor ajuste foi obtido para o modelo de norma de reação hierárquica com um passo $\left(\mathrm{HRNM}_{1 \mathrm{~s}}\right)$. As estimativas de herdabilidade direta para este modelo variaram de 0,17 a 0,67 e a herdabilidade materna de 0,02 a 0,11 com gradiente ambiental crescente. As correlações mais baixas entre as classificações dos reprodutores foram obtidas em comparação com as $\mathrm{HRNM}_{1 \mathrm{~s}}$, em ambientes com baixo e alto manejo, confirmando a presença de interações genótipo x ambiente. Conclusões: Recomendamos a aplicação mais ampla da avaliação genética em búfalos visando identificar genótipos ótimos em ambientes específicos.

Palavras-chave: ambiente; avaliação genética; búfalos; correlação de classificação; genótipos; gradiente ambiental; Inferência Bayesiana; interação genótipo por ambiente; modelos de norma de reação; reação hierárquica; valor genetico. 


\section{Introduction}

In recent years, the growth of Bubaline livestock in Brazil has been proportionally higher than cattle (Malhado et al., 2007). There are now approximately $1,319.5$ million head of buffalo in Brazil, with $3.37 \%$ increase rate in 2015 (IBGE, 2015). The increase in buffalo numbers in this country has mainly been driven by the unique chemical characteristics of milk and meat, greater resistance to infection by endo and ectoparasites (Bastianetto, 2009), and to a broad ecological tolerance allowing greater occupancy of available areas (Garcia et al., 2016). Buffaloes also have higher fertility, increased longevity and lower mortality rates as compared to cattle (Bernades, 2007).

The increase in buffalo numbers in Brazil provided the basis for several studies, mainly in dairy buffaloes (Sesana et al., 2014; Malhado et al., 2017; Rezende et al., 2017). Nevertheless, there is still a lack of knowledge of genetic parameter estimates in buffaloes used for meat production. Although such GxE effects are well known in cattle (Mattar et al., 2011; Ambrosini et al., 2012; Rezende et al., 2019), pigs (Knap and $\mathrm{Su}, 2008$ ) and quail (Oroian, 2010), to the best of our knowledge no published studies on genotype by environment interactions (GxE) in buffaloes are available - and this critical information is of paramount importance in a large country such as Brazil, where buffalo herds may be farmed in a wide variety of bioclimatically and ecologically distinct environments. If GxE are not considered, genetic values can be biased thereby reducing the response to selection (Streit et al., 2012).

Various reaction norm (RN) models have been used to describe phenotypic change over environmental gradients. Such models can detect gradual changes in the reaction norm by examining the performance of genotypes along the environmental gradient (De Jong, 1995). The advantage of these models is that the selection response can be predicted, not only in phenotypic expression in the environment, but also in the environmental sensitivity of the changes in the environment (De Jong and Bijma, 2002). Therefore, the objective of this study was to quantify genotype by environment interaction in the Mediterranean water buffalo in Brazil using reaction norm models. The phenotypic trait used for the analysis was body weight adjusted to 205 days of age (W205).

\section{Materials and Methods}

\section{Data}

Data for Mediterranean water buffaloes born between 1990 and 2014 were collected from five farms ascribed to the Brazilian Buffaloe Improvement Program (PROMEBUL), and located in the North (1), Northeast (1), South (2) and Southeast (1) regions of Brazil. The initial database consisted of 5,280 observations at 205 days of age (W205). However, not all the data were usable and the following records were excluded from our analysis: 605 animals with weight records lower than 70 and higher than $360 \mathrm{~kg}, 90$ animals pertaining to contemporary groups (CG) with 3 or less animals with weights above 3 standard deviations from the CG mean. Additionally, 778 records were removed because they had less than two offspring. Finally, 194 records were not used because they were unrelated to the study dataset. The remaining 3,613 records, with an average of $195.3 \pm$ $32.7 \mathrm{~kg}$ to $\mathrm{W} 205$, were used in the analyses.

We used the routines created by Cardoso (Cardoso, 2010) in SAS (SAS, 2019) to collate, format, and describe the data statistically. CGs were created to group individuals into common production environments based on year, season, herd and sex. Birth periods were grouped into four classes (period 1: September, October and November; period 2: December, January and February; period 3: March, April and May; and period 4: June, July and August).

The connections between CGs, based on the genetic links (minimum of 10) was assessed with the AMC software (Roso and Schenkel, 2006). In preparing the pedigree file, only connected CGs were included, resulting in three 'archipelagos': the first, with $113 \mathrm{CG}$ and 3,613 animals; the 
second, with $31 \mathrm{CG}$ and 127 animals; and the third, with $12 \mathrm{CG}$ and 55 animals. For the rest of the analysis, we only used data from the main archipelago.

\section{Data analysis}

The initial analysis was performed with the standard animal model (AM) to obtain estimates of the environmental gradient based on CGs. INTERGEN software (Cardoso, 2010) adjusts Bayesian hierarchical models. This software uses parameters set at structured levels to assess the diversity of common situations in animal performance data. In the case of the reaction norm models, the genetic value of the animal is obtained by a function of an environmental average related to the $\mathrm{CG}$ record. Thus, for each environmental level a specific genetic value is allocated to each animal (Cardoso and Tempelman, 2012).

The standard animal model (AM), ignoring GxE interactions, was used to estimate genetic values and environmental effects: AM: $y_{i j}=x_{i} \beta+$ $X_{j}+a_{i}+m_{i}+e p_{i}+e_{i j}[1]$. Where, $y_{i j}$ is a record of an individual buffalo $i$ in environment $j$; $\beta$ a vector of fixed effects (linear and quadratic coefficients for age of buffalo); $x_{i}$, being its corresponding incidence vector; $X_{j}$ is the distributed random effect of the environment $j$ (CG effects); $a_{i}$ is the additive genetic value of animal $i ; m_{i}$ is the maternal genetic value of the animal $i$; $e p_{i}$ is the maternal permanent environmental effect as a covariate in the reaction norm model; and, $e_{i j}$ is the residual error. The covariance between direct and maternal genetic effects was set to zero.

Two approaches were used to estimate hierarchical reaction norm models: 1) hierarchical RN models based on a 2-step procedure - $\mathrm{HRNM}_{2 \mathrm{~s}}$, and; 2) hierarchical RN models based on 1-step procedure - $\mathrm{HRNM}_{1 \mathrm{~s}}$. The first model, proposed by Kolmodin (2002), uses the AM solutions as covariates: $H_{R N M}$ : $y_{i j}=x_{i} \beta+\Phi X_{j}+a_{i}+m_{i}+e p_{i}+b_{1 i} \hat{X}_{j}+b_{2 i} \hat{X}_{j}+$ $e_{i j}[2]$. Here $\Phi$ is the fixed regression coefficient; $a_{i}$ corresponds to the additive genetic effect or intercept of animal $i ; m_{i}$ is the maternal genetic value or intercept of animal $i ; e p_{i}$, is the maternal permanent environmental effect; $b_{1 i}$ is the random regression coefficient or RN slope of animal $i ; b_{2 i}$ corresponds to the maternal random regression coefficient or RN maternal slope; $i$ is the environment represented by $\hat{X}_{j}$; whereas $\hat{X}_{j}$ is the predictor of $X_{j}$ obtained in the Eq. [1]; and, $e_{i j}$ is the residual error.

The second approach, developed by $\mathrm{Su}$ et al. (2006), uses estimates of environmental effects as covariate to obtain RN of the animals - meaning that $\mathrm{Xj}$ and $b_{i}$ are jointly estimated following: $\operatorname{HRNM}_{1 s}: Y i j=x_{i} ß+X_{j}+a_{i}+m_{i}+$ $e p_{i}+b_{1 i} X_{j}+b_{2 i} X_{j}+e_{i j}[3]$.

The direct additive and maternal genetic variances for a given environment $\mathrm{X}, \sigma_{A}{ }^{2} \mid X_{j}$ and $\sigma_{M}^{2} \mid X_{j}$ were obtained as follows: $\sigma_{A}^{2} \mid X_{j} \stackrel{j}{=} v a r$ $\left(a_{i}+b_{1 i} X_{j}\right)=\sigma_{a}^{2}+\sigma_{b}^{2} X_{j}^{2}+2 \sigma_{a, b} X_{j}$ and $\sigma_{M}^{2} \mid X_{j}$ $=\operatorname{var}\left(a_{i}+b_{2 i} X_{j}^{a}\right)=\sigma_{m}^{2}+\sigma_{b}^{2} x X_{j}^{2}+2 \sigma_{a, b} X_{j}$

The heritability was estimated by the ratio of genetic variance to phenotypic variance (genetic + environmental) as:

$$
\begin{aligned}
& h_{a}^{2} \mid X_{j}=\frac{\sigma_{A}^{2} \mid X_{j}}{\sigma_{A}^{2}\left|X_{j}+\sigma_{M}^{2}\right| X_{j}+\sigma_{p e}^{2}+\sigma_{e}^{2} \mid X_{j}} \\
& h_{m}^{2} \mid X_{j}=\frac{\sigma_{M}^{2} \mid X_{i}}{\sigma_{A}^{2}\left|X_{j}+\sigma_{M}^{2}\right| X_{j}+\sigma_{p e}^{2}+\sigma_{e}^{2} \mid X_{j}}
\end{aligned}
$$

The estimates of variance components were obtained through a Bayesian approach using a Markov Chain Monte Carlo (MCMC) method. This was achieved using the following procedure: a) running a pilot analysis with 25,000 cycles, 2,500 of burn-in and 5 of thinning; b) using the variance-component samples - Varcompsam and the R program (R DEVELOPMENT CORE TEAM, 2008) - Bayesian Output Analysis BOA (Smith, 2007). The Raftery and Lewis (1993) test was applied to ascertain chain size and thinning, and; c) the burn-in was assessed by Heidelberg and Welch (1983) criterion. The analyses ultimately used chains varying from 440,000 to $1,350,000$ cycles.

The chain convergence analysis for the models was assessed by Geweke`s $\mathrm{Z}$ criterion 
(Geweke, 1992) and applied to the conditional distribution of data, denoted by ${ }^{l_{i}^{(j)}}=\log p$ $\left(y \mid \theta^{(j)}, M_{i}\right)$ for the initial samples (first 10\%) and the last part of Markov chain (last 50\%). This is similar to the approach proposed by Brooks and Robert (1998) using the following statistic:

$$
Z_{i}=\frac{\left(\bar{l}_{i}^{A}-\bar{l}_{i}^{B}\right)}{\sqrt{\frac{1}{n_{A}} \hat{S}_{i}^{A}(O)+\frac{1}{n_{B}} \hat{S}_{i}^{B}(O)}} \text { were in } \bar{l}_{i}^{A}=\frac{1}{n_{A}} \sum_{j=1}^{n_{A}} l_{i}^{(j)}, \bar{l}_{i}^{B}=\frac{1}{n_{B}} \sum_{j=n}^{m} l_{i}^{(j)}
$$

In which $\mathrm{n}_{\mathrm{A}}=270.000, \mathrm{n}_{\mathrm{B}}=1.350 .000$, $\mathrm{n}^{*}=1.350 .001$ with $\hat{S}_{i}^{A}(O)$ and $\hat{S}_{i}^{B}(\mathrm{O})$, being the respective statistics for spectral density in zero frequency obtained through SPECTRA approach of SAS, for the first $n_{A}$ and last $n_{B}$ cycles of MCMC of length $m$. The absolute values of $\mathrm{Z}_{\mathrm{i}}$ score (two-tailed) indicated rejection for the convergence test. The fit of the models $\left(\mathrm{AM}, \mathrm{HRNM}_{2 \mathrm{~s}}\right.$ and $\mathrm{HRNM}_{1 \mathrm{~s}}$ ) was verified using three criteria: Deviance Information Criterion (DIC) (Spiegelhater et al., 2002); Deviance based on Conditional Predictive Ordinate (DCPO) (Gelfand, 1996); and Deviance based on Bayes Factors (DBF).

\section{Results}

The Geweke test $(\mathrm{Z})$ indicates that the AM and $\mathrm{HRNM}_{2 \mathrm{~s}}$ models converged at $5 \%(\mathrm{p}>0.05)$ for all parameters, while the $\mathrm{HRNM}_{1 \mathrm{~s}}$ model converged at $1 \%(\mathrm{p}>0.01)$ (Table 1$)$.

Table 1. Geweke's Test $(Z)$ of convergence for variance components by different models.

\begin{tabular}{ccccc}
\hline & & & Models & \\
\hline Parameters & Geweke Test & AM & HOHRNM $_{1 \mathrm{~s}}$ & HRNM $_{2 \mathrm{~s}}$ \\
\hline VC1 & $\mathrm{Z}$ & -0.19 & 1.19 & 1.45 \\
& $\mathrm{VC} 2$ & 0.85 & 0.23 & 0.15 \\
\hline VC2 & $\mathrm{Z}$ & 0.69 & -0.78 & -1.35 \\
& $\mathrm{VC} 4$ & 0.49 & 0.44 & 0.18 \\
\hline VC3 & $\mathrm{Z}$ & -1.05 & -1.04 & -1.28 \\
& $\mathrm{VC6}$ & 0.29 & 0.30 & 0.20 \\
\hline VC4 & $\mathrm{Z}$ & 0.56 & -1.55 & -1.32 \\
& $\mathrm{VC} 8$ & 0.58 & 0.12 & 0.19 \\
\hline VC5 & $\mathrm{Z}$ & -0.08 & 1.43 & 1.85 \\
& P-value & 0.93 & 0.15 & 0.06 \\
\hline VC6 & $\mathrm{Z}$ & 0.21 & -0.51 & 0.82 \\
& P-value & 0.83 & 0.61 & 0.41 \\
\hline VC7 & $\mathrm{Z}$ & & -2.27 & -0.95 \\
& P-value & & 0.02 & 0.34 \\
\hline VC8 & $\mathrm{Z}$ & & -1.11 & -1.29 \\
& P-value & & 0.27 & 0.19 \\
\hline VC9 & $\mathrm{Z}$ & & 1.67 & 1.25 \\
& P-value & & 0.09 & 0.21 \\
\hline
\end{tabular}

VC1 - Variance of Contemporary Group (HRNM); VC1 - Variance of direct genetic effect (AM); VC2 - Variance of reaction norm intercept (Direct Effect) (HRNM); VC2 - Variance of maternal genetic effect (AM); VC3 - Variance of reaction norm slope (Direct Effect) (HRNM); VC3 - Correlation between the variance of direct and maternal genetic effect (AM); VC4 - Correlation between the reaction norm intercept and slope (Direct Effect) (HRNM); VC4 - Variance of maternal permanent environmental effect (AM); VC5 - Variance of reaction norm intercept (Maternal Effect) (HRNM); VC5 - Variance of Contemporary Group (AM); VC6 - Variance of reaction norm slope (Maternal Effect) (HRNM); VC6 - Variance of residual error (AM); VC7 - Correlation between the reaction norm intercept and slope (Maternal Effect) (HRNM); VC8 - Variance of maternal permanent environmental effect (HRNM); VC9 - Variance of residual error (HRNM). 
Based on the two criteria for model comparison (DIC and DBF), the HRNM1s model had a better fit (Table 2).

Table 2. Deviance based on Bayes Factors (DBF), Deviance Information Criterion (DIC) and Deviance based on Conditional Predictive Ordinate (DCPO).

\begin{tabular}{lccc}
\hline Models & DIC & DCPO & BDF \\
\hline Animal Model & $36353,23^{(3)}$ & $34031,45^{(3)}$ & $32869,11^{(3)}$ \\
HRNM $_{1 \mathrm{~s}}$ & $33016,15^{(1)}$ & $33657,24^{(2)}$ & $32827,13^{(1)}$ \\
HRNM $_{2 \mathrm{~s}}$ & $33472,1^{(2)}$ & $33607,42^{(1)}$ & $32858,77^{(2)}$ \\
\hline
\end{tabular}

1, 2 and 3: display the best model fit.

The environmental gradient model results ranged from -33 to $47 \mathrm{~kg}$, characterizing environmental levels from low to high management (Figure 1). The direct heritability estimates of $\mathrm{HRNM}_{1 \mathrm{~s}}$ ranged from 0.17 to 0.67 and the maternal heritability from 0.02 to 0.11 (Figure 1).

The posterior mean (for $\mathrm{HRNM}_{1 \mathrm{~s}}$ following data adjustment) of the correlation between the slope and the intercept in the reaction norm was high for maternal $(0.82 \pm 0.06)$ and direct effects $(0.87 \pm 0.15)$. Animals with higher direct and maternal genetic values (for weight at 205 days) responded to the environmental gradient (Figure 2 and 3$)$.

The slopes of the reaction norms ranged from -1.47 to 1.32 degrees for direct effects, in which $47.06 \%(2,046)$ of the animals can be classified as robust and intermediate genotypes (inclinations between -0.20 and 0.20 degrees). Plastic genotypes ( -1.47 to -0.20 and 1.32 to 0.20$)$ were observed in $52.94 \%$ (2301) of the animals.

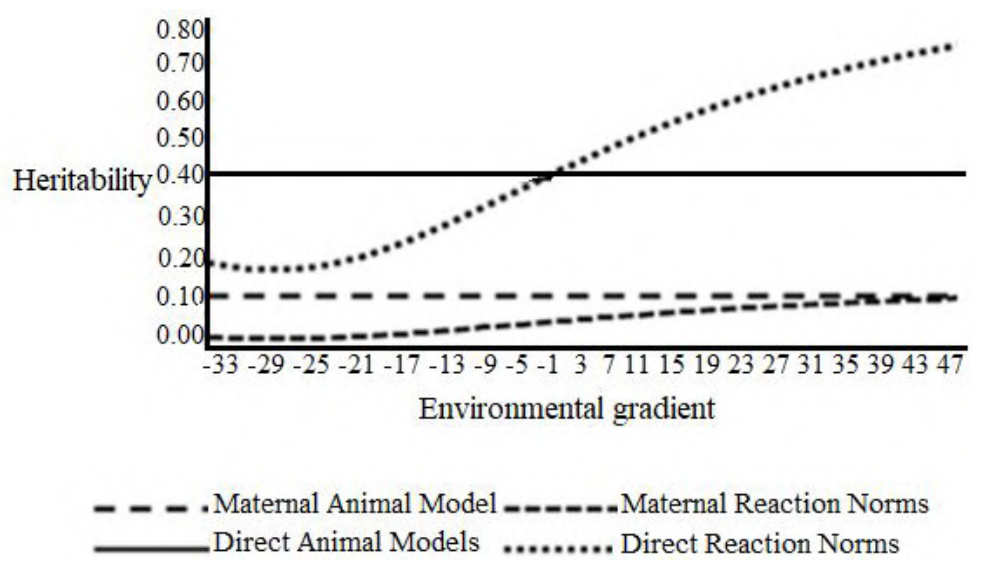

Figure 1. Heritability of W205 for direct and maternal effects in different models across environmental gradient.

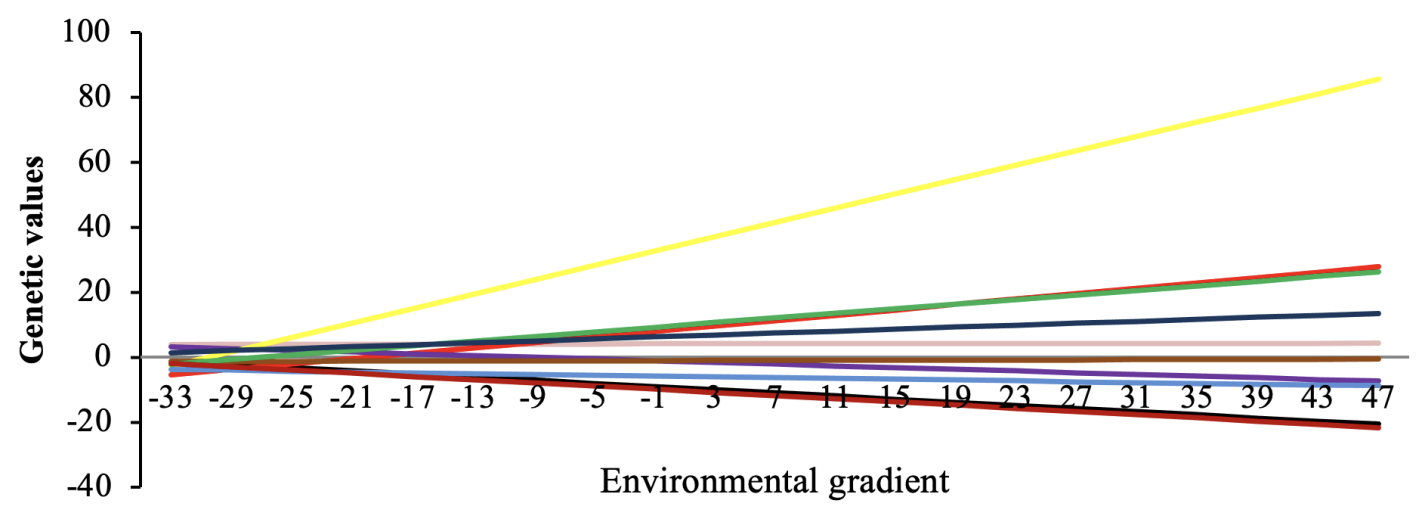

Figure 2. Reaction norm by environmental gradient for W205 for direct effect for the 10 sires with the highest number of offspring. 


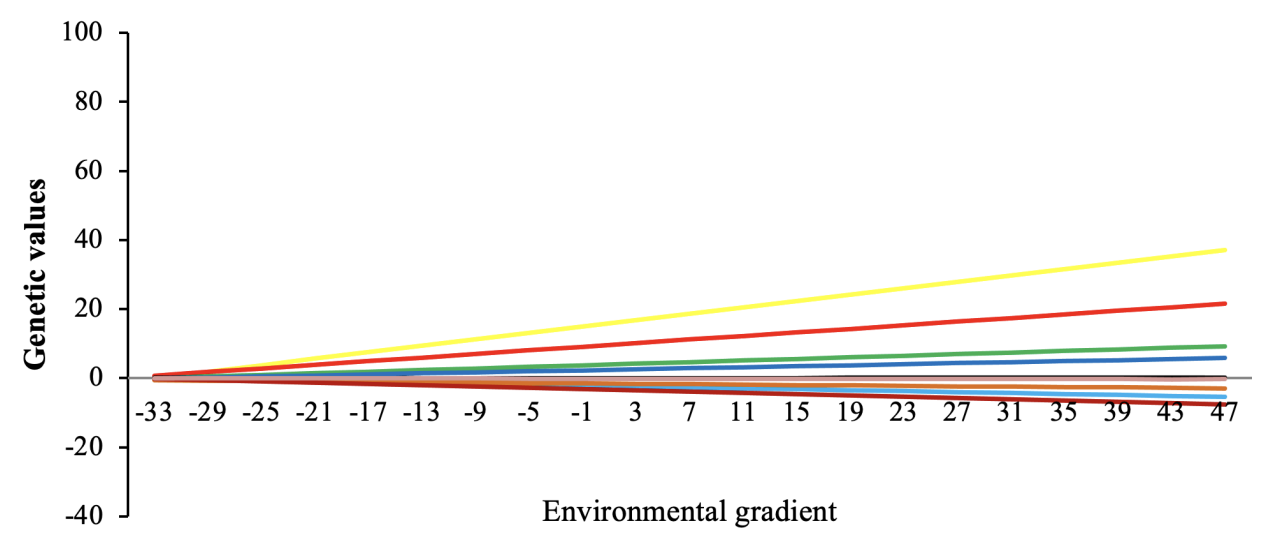

Figure 3. Reaction norm by environmental gradient for W205 for maternal effect for the 10 sires with the highest number of offspring.

The Spearman correlations among the ratings of 50\% sires with higher genetic values ranged from -0.40 to 0.97 in different environments and models. When all sires were considered, the values ranged from 0.27 to 0.99 (Table 3). The lowest values were found in the comparison of Low-HRNM $_{1 \mathrm{~s}}$ and High-HRNM $1 \mathrm{~s}$, confirming the presence of genotype by environment interactions.

The estimated correlations among genetic values obtained via the HRNM1s model in different environments were from -0.09 to 1.00 for the direct effect (Figure 4) and from -0.22 to 1.00 for the maternal effect (Figure 5).

Table 3. Spearman rank correlations among the classifications of $50 \%$ of the sires with higher genetic values under the diagonal and with $100 \%$ of sires above the diagonal obtained by the animal model (AM) and by hierarchical reaction norm model $\left(\mathrm{HRNM}_{1 \mathrm{~s}}\right)$ at different environmental levels.

\begin{tabular}{lcccc}
\hline Models & AM & HRNM $_{1 \mathbf{s}}$ (low) & HRNM $_{1 \mathbf{s}}$ (median) & HRNM $_{\mathbf{1 s}}$ (high) \\
\hline $\mathrm{AM}$ & & $0.47(<.0001)$ & $0.93(<.0001)$ & $0.91(<.0001)$ \\
$\mathrm{HRNM}_{1 \mathrm{~s}}$ (low) & $-0.10(<.0001)$ & & $0.34(<.0001)$ & $0.27(<.0001)$ \\
$\mathrm{HRNM}_{1 \mathrm{~s}}$ (medium) & $0.79(<.0001)$ & $-0.32(<.0001)$ & & $0.99(<.0001)$ \\
$\mathrm{HRNM}_{1 \mathrm{~s}}$ (high) & $0.73(<.0001)$ & $-0.40(<.0001)$ & $0.97(<.0001)$ & \\
\hline
\end{tabular}

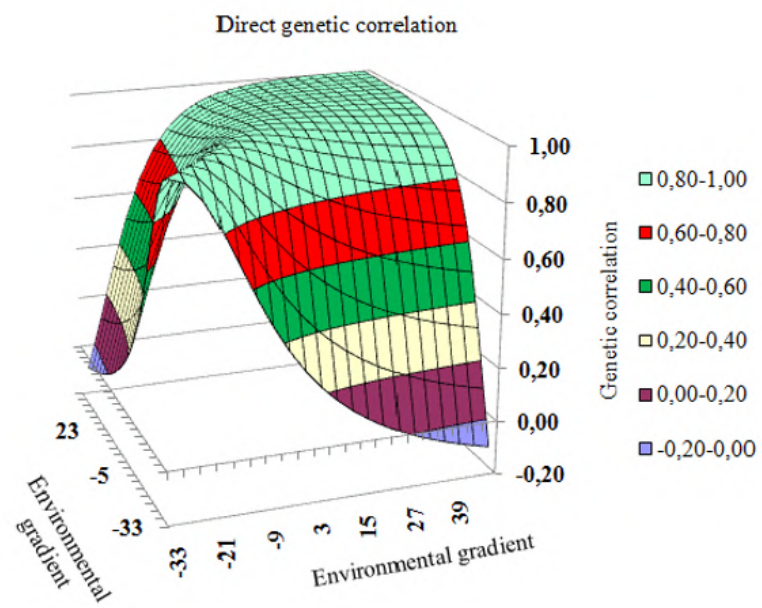

Figure 4. Response surface for correlations between direct genetic values in the environmental gradient. 


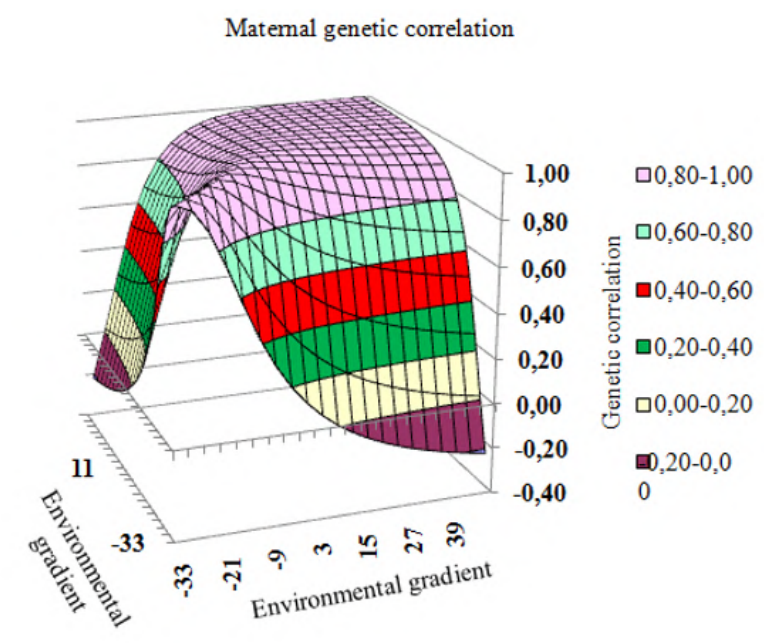

Figure 5. Response surface for correlations between maternal genetic values in the environmental gradient.

\section{Discussion}

This result for model comparison (table 2) is in accordance with several previous studies assessing standardized post-weaning gain for Devon (Côrrea, 2009), Hereford (Cardoso et al., 2011) and Canchim (Mattar et al., 2011) cattle breeds. The heritability estimates (direct and maternal) for the animal model (AM) were 0.38 and 0.12, respectively. Malhado et al. (2008), using the Restricted Maximum Likelihood (REML) method, found higher values $(0.42 \pm$ $0.06)$ for direct heritability and lower values $(0.05 \pm 0.03)$ for maternal heritability for W250 in this breed.

The genetic variances (direct and maternal) and heritability increased with increasing increments of the environmental gradient. Such strong environmental associations provide compelling evidence that the values of genetic parameters are dependent on the environment in which animals are bred. Such effects can accentuate the differences between more responsive animals as demonstrated in several studies on cattle (Cardoso and Tempelman, 2012; Kolmodini, 2002; SU et al., 2006). Using the HRNM model, Corrêa et al., 2009 and Cardoso et al., 2011 recorded direct heritability values close to the range studies observed in the current one for post-weaning gain of Devon cattle (0.29 to 0.70$)$ and Hereford cattle (0.07 to 0.64$)$.
According to the environmental gradient response, specifically, the more favorable the environment, the greater the difference in genetic values since under favorable environmental conditions the animals are better able to express their genetic potential. This result agrees with other standardized studies for growth and production in cattle (Correa, 2009; Kolmodin, 2002; Fikse et al., 2003). The GxE effect was evident observing the change in sires' genetic values (both direct and maternal) along the environmental gradient (Figures 2 and 3). The slopes of the reaction norms demonstrate the importance of considering the $\mathrm{GxE}$ in genetic evaluations. This information can be used to get better performance in different environments by selecting highly productive robust genotypes, or plastic genotypes that respond positively to environmental improvement.

The results of Spearman correlations make it possible that the best sires in the low-level environments are not necessarily best in the middle- and high-level environments in reason of the low correlations $(-0.40$ and 0.27$)$. The highest correlations (0.97 and 0.99) were between Medium-HRNM ${ }_{1 \mathrm{~s}}$ and High-HRNM ${ }_{1 \mathrm{~s}}$, indicating an absence of $\mathrm{GxE}$ when considering only these two environments.

Thus, sires selected on progeny information bred in medium-level environments can be used in high-level environments. Comparing AM 
with $\mathrm{HRNM}_{1 \mathrm{~s}}$, the highest correlations were with Medium-HRNM $1 \mathrm{~s}$, demonstrating that the animal model corrects for a medium production environment. However, genetic assessments not considering GxE can lead to inaccurate use of sires, especially inlow-level environments. Before 2004 genetic evaluations for Mediterranean buffaloes did not exist in Brazil.

With the release of information based on the BLUP (best linear predictors not addicted) methodology in 2004, genetic values of Brazilian buffalo have been predicted and sire selection has started to be based on this criterion. However, as the usual genetic evaluation does not consider GxE, the gains may be lower than expected, especially in production environments with lower-level management.

Ambrosini et al. (2014) in cattle have not reported a significant change in classification when comparing the low, medium and high levels of $\mathrm{HRNM}_{1 \mathrm{~s}}$. The fact that our study employed animals from four regions of Brazil may have contributed to this divergence. However, Corrêa et al. (2009) found a high change in the sires' classification from Devon cattle, when considering the RNM.

The genetic correlation in the medium and high levels of the environmental gradient is high and positive (Figure 4 and 5), falling rapidly as the environment becomes unfavorable, with negative values between the environmental gradient extremes. Thus, selection in medium and high environments is equivalent. In practical terms, some animals are adapted and productive in adverse environments, while other animals have superior performance in the most favorable environments. These results are in agreement with those recorded for post-weaning gain in Devon cattle (Côrrea et al., 2009), for protein yield in dairy cattle, and for yearling weight in Canchim cattle (Mattar et al., 2011).

In general, GxE were identified by the best fit model $\left(\mathrm{HRNM}_{1 \mathrm{~s}}\right)$. This was supported by the heritability change, by the correlation values between the slope and the intercept of the reaction norm, and by the change in classification. In addition, there was a change in genetic values with a greater effect for direct values.

The data suggests that buffaloes are plastic and robust animals, providing considerable scope for selection for productivity traits in each specific environment. Genetically superior (more productive) animals in medium- and high-level environments are different from those in lowlevel environments. Thus, genetic evaluation programs in buffalo are required to identify superior animals in certain environments.

\section{Declarations}

\section{Funding}

This study was financed by the Coordination for the Improvement of Higher Education Personnel (CAPES - Brazilian Federal Government Agency under the Ministry of Education).

\section{Conflicts of interest}

The authors declare they have no conflicts of interest with regard to the work presented in this report.

\section{Author contributions}

Fernando B Rodrigues - collected the dataset, statistical analysis, and wrote the manuscript. Carlos HM Malhado - administered the project. Paulo LS Carneiro - critical reading of the manuscript. Diego P Ambrosini - support in statistical analysis. Marcos PG Rezende statistical analysis and wrote the manuscript. Riccardo Bozzi - critical reading of the manuscript. Jiuzhou Song - conception of the study and reviewed the manuscript.

\section{References}

Ambrosini DP, Bracini Neto J, Martins Filho R, Malhado CHM, Afonso P, Carneiro P. Reaction norms of direct and maternal effects for weight at 205 days in Polled Nellore cattle in Northeastern Brazil. Arch Tierzucht 2014; 57:1-11. DOI: https:/doi.org/10.7482/0003-9438-57-032 
Ambrosini DP, Carneiro P, Bracini Neto J, Malhado CHM, Martins Filho R, Cardoso FF. Genotype $\mathrm{x}$ environment interaction for yearling weight in Polled Nellore cattle in Northeast Brazil. Pesq agropec bras 2012; 47:1489-1495. DOI: https://doi.org/10.1590/S0100-204X2012001000011

Bastianetto E. Water buffalo breed in Brazil: situation and perspective. $\mathrm{R}$ Bras Saud Reprod Anim 2009; 6:8-103. DOI: http://www.cbra.org.br/pages/publicacoes/rbra/ download/p98-103.pdf

Bernardes O. Buffaloes breeding in Brasil: position and economic relevancy. R Bras Saud Reprod Anim 2007; 31:293-298. DOI: https://doi.org/10.4081/ijas.2007.s2.162

Brooks SP, Roberts GO. Convergence assessment techniques for Markov chain Montes Carlo. Stat Comp 1998; 8:319-335. DOI: https://link.springer. com/content/pdf/10.1023/A:1008820505350.pdf

CardosoFF.Application of Bayesian inference in animal breeding using the Intergen Program Manual of version 1. 2. Bagé-RS: Embrapa Pecuária Sul. 2010.

Cardoso FF, Tempelman RJ. Linear reaction norm models for genetic merit prediction of angus cattle under genotype by environment interaction. J Anim Sci 2012; 90:2130-2141. DOI: $\underline{\text { https://doi.org/10.2527/jas.2011-4333 }}$

Cardoso LL, Barccini Neto J, Cardoso FF, Cobuci JA, Biassus IO, Barcellos JOJ. Hierarchical bayesian models for genotype $\mathrm{x}$ environment estimates in post-weaning gain of Hereford bovine via reaction norms. R Bras Zootec 2011; 40:294-300. DOI: https://doi.org/10.1590/S1516-35982011000200009

Corrêa MBB, Dionello NJL, Cardoso FF. Genotype by environment interaction characterization and model comparison for post weaning gain adjustment of Devon cattle via reaction norms. R Bras Zootec 2009; 38:1468-1477. DOI: https://doi.org/10.1590/S1516-35982009000800010

De Jong G. Phenotypic plasticity as a product of selection in a variable environment. Amer Nat 1995; 145:493-512. DOI: https://www.jstor.org/stable/2462965
De Jong G. Bijma P. Selection and phenotypic plasticity in evolutionary biology and animal breeding. Livest Prod Sci 2002; 78:195-214. DOI: https://doi.org/10.1016/S0301-6226(02)00096-9

Fikse WF, Rekaya R, Weigel KA. Assessment of environmental descriptors for studying genotype by environment interaction. Livest Prod Sci 2003; 82:223-231. DOI: https://doi.org/10.1016/S0301-6226(03)00009-5

Garcia HA, Ramirez OJ, Rodrigues CMF, Sanchez RG, Bethencourt AM, Perez GDM, Minervino AHH, Rodrigues AC, Teixeira MMG. Trypanosoma vivax in water buffalo of the Venezuelan Llanos: An unusual outbreak of wasting disease in an endemic area of typically asymptomatic infections. Vet Parasitol 2016; 230:49-55. DOI: https://doi.org/10.1016/j.vetpar.2016.10.013

Gelfand AE. Model determination using samplingbased methods. In: Markov Chain Monte Carlo in practice. (Eds: WR Gilks, S Richardson, DJ Spiegelhalter) pp. 145-161. (London: Champman and Hall). 1996.

Geweke J. Evaluating the accuracy of samplingbasead approaches to the calculation of posterior moments. In: Bayesian statisti. (Eds: JM Bernardo, JO Berger, AP Dawid, AFM Smit) pp. 1-21. (New York: Oxford University). 1992.

Heidelberger P, Welch P. Simulation run length control in the presence of an initial transient. Operat Res 1983; 31:1109-1144. DOI: $\underline{\text { https://www.jstor.org/stable/170841 }}$

Knap PW, Su G. Genotype by environment interaction for litter size in pigs as quantified by reaction norms analysis. Anim 2008; 2:1742-1747. DOI: https://doi.org/10.1017/S1751731108003145

Kolmodin R, Strandberg E, Madsen P, Jensen J, Jorjani $\mathrm{H}$. Genotype by environment interaction in Nordic dairy cattle studied using reaction norms. Acta Agric Scand A Anim Sci 2002; 52:11-24. DOI: https://doi.org/10.1080/09064700252806380

Malhado CHM, Rezende MPG, Malhado ACM, Azevedo DMMR, Souza JC, Carneiro PLS. Comparison of Nonlinear Models to Describe the 
Growth Curves of Jaffarabaddi, Mediterranean and Murrahbuffaloes.JAgrSciTech2017;19:1485-1494. https://pdfs.semanticscholar.org/aa77/12ea8e 271a886b8b1520030d06651e76241e.pdf? $\mathrm{ga}=2.59968621 .1129624986 .1595351376-$ $\underline{1607104821.1592931039}$

Malhado CHM, Ramos AA, Carneiro PLS, Azevedo DMMR, Martins Filho R, Souza JC. Improvement and population structure of Mediterranean water buffaloes raised in Brazil. Pesq agropec bras 2008; 43:215-220. DOI: https://doi.org/10.1590/S0100-204X2008000200009

Malhado CHM, Ramos AA, Carneiro PLS, Souza JC, Piccinin A. Genetic and phenotypic parameters for milk production of Murrah buffaloes. R Bras Zootec 2007; 36:376-379. DOI: https://doi.org/10.1590/S1516-35982007000200014

Mattar M, Silva LOC, Alencar MM, Cardoso FF. Genotype x environment interaction for long-yearling weight in Canchim cattle quantified by reaction norm analysis. J Anim Scienc 2011; 89:2349-2355. DOI: https://doi.org/10.2527/jas.2010-3770

Oroian T, Orain R, Pascalãu S, Oroian E, Dronca D. Aspects of the Genotype-Environment Interaction at the Japanese Quail (Coturnix-Coturnix Japonica). Anim Scienc Biotechnol 2010; 43:195-198. DOI: http://spasb.ro/index.php/spasb/article/view/756/713

R Development Core Team. R: A language and environment for estatistical computing. Viena 2008, Áustria: $\mathrm{R}$ foundation for statistical computing: [http://www.R-project.org].

Raftery AE, Lewis SM. One long run with diagnostics: implementation strategies for markov chain Monte Carlo. Stat Scienc 1993; 7:493-497. DOI: https://projecteuclid.org/download/pdf 1/euclid. $\underline{\text { ss/1177011143 }}$

Rezende MPG, Ferraz PC, Carneiro PLS, Malhado CHM. Phenotypic diversity in buffalo cows the Jafarabadi, Murrah and Mediterranean breeds. Pesq agropec bras 2017; 52:663-669. DOI: https://doi.org/10.1590/s0100-204x2017000800012
Rezende MPG, Malhado CHM., Biffani S, Carneiro PLS, Carrilo JÁ, Bozzi R. Genotype-environment interaction for age at first calving in Limousine and Charolais cattle raised in Italy, employing reaction norm model. Livest Sci 2020; 232;103912. DOI: https://doi.org/10.1016/j.livsci.2019.103912

Roso VM, Schenkel FS. AMC: a computer program to assess the degree of connectedness among contemporary groups. In: World Congress on Genetics Applied to Livestock Production. 2006. pp. 26-27. (Belo Horizonte). https://www. researchgate.net/publication/285687222 AMC A computer program to assess the degree of connectedness among contemporary groups

SAS Institute Inc. SAS/STAT. SAS Institute Inc., 2019.

Sesana RC, Baldi F, Borquis RRA, Bignard AB, Hurtado-Lugo NA, El Faro L, Albuquerque LG, Tonhati H. Estimates of genetic parameters for total milk yield over multiple ages in Brazilian Murrah buffaloes using different models. Genet Mol Res 2014; 13:2784-2795. DOI: http://dx.doi.org/10.4238/2014.April.14.7

Smith BJ. Bayesian output analysis program (BOA) version 1.1.7.2 user's manual. Iowa: University of Iowa. 2007.

SpiegelhalterDJ, BestNG, CarlinBP, VanderLindeA. Bayesian measures of model complexity and fit (with discussion). J R Stat Soc B 2002; 64:583-639. DOI: https://rss.onlinelibrary.wiley.com/doi/ pdf/10.1111/1467-9868.00353

Streit M, Reinhardt F, Thaller G, Bennewitz J. Reaction norms and genotype-by-environment interaction in the German Holstein dairy cattle. J Anim Breed Genet 2012; 129:380-389. DOI: https://doi.org/10.1111/j.1439-0388.2012.00999.x

Su G, Madsen P, Lund MS, Sorensen D, Korsgaard IR, Jensen J. Bayesian analysis of the linear reaction norm model with unknown covariates. J Anim Scienc 2006; 84:1651-1657. DOI: https://doi.org/10.2527/jas.2005-517 